\title{
ORGANIZATION CLIMATE AND JOB SATISFACTION IN COLEGIO DE SAN JUAN DE LETRAN - BATAAN
}

\author{
AP Edessa G. Flordeliz \\ Colegio de San Juan de Letran-Bataan
}

Article DOI: https://doi.org/10.36713/epra4040

\begin{abstract}
This descriptive study in nature was designed to determine the relationship of dimensions of organizational climate and job satisfaction of teachers in Colegio de San Juan de Letran-Bataan. Forty two (42) of collegiate and basic education faculty were the respondents. The study adopted Organizational Climate Descriptive Questionnaire (OCDQ) developed by (Croft, 1963) to know the type of organizational climate, were used for data collection. It is found that there is significant relationship between dimensions of transformation and diversity and Colegio's image of organizational climate and job satisfaction while there is no significant relationship between dimensions of trust, training and development, leadership, employee's wellness, communication, performance management, remuneration and rewards, teamwork and work environment of organizational climate and job satisfaction.
\end{abstract}

KEY WORDS: Organization climate, job satisfaction, employee, management, leadership

\section{INTRODUCTION}

Acknowledged as the most imperative factor for human knowledge growth and progress, education, has its impact on the human advancement connected to the globalization process. According to the National Policy of Education (1969), "Education is an important venture for national development which depends upon quality leadership, which is provided by quality education.

Thus, making any educational institution a fundamental part of the society.

Anyone who spends time in schools will definitely determines how one school can sense different from other schools. School climate is a universal articulation that denotes particularly the feel, atmosphere, tone, ideology, or milieu of a school. Just as individuals have personalities, so too do schools; a school climate may be thought of as the personality of a school.

School climate has become a comprehensive paradigm that researchers often use loosely to group together studies of school environment, learning environment, learning climate, sense of community, leadership, academic climate, and social climate.

This broad application reveals both the strength and weakness of school climate (Liano, 2001). Though it is a useful integrating concept on the one hand, but it also suffers from a lack of clear definition. The word sometimes obscures, rather than creates, understanding.

As the identification of the organizational climate of school is reliant upon the faculty's perception of interaction within the organization, it would be expected that the values, needs, and expectations of the individual teacher and the particular - characteristic of the organization would play a substantial part in influencing the impressions formed.

School organization like any other organization has definite characters, structures and belief. To achieve organization's goals and also gratifies his necessities as part of the organization, an individual does his obligation well. The organization, to keep his part of the accord, functions according to a set of ideologies and customary responsibilities to achieve its objectives and the same sense of controlling the members of the organization.

The overall purpose of this study is to assess the interactive impact of selected factors of organizational climate of Colegio de San Juan de Letran-Bataan focusing specifically on trust, training and development, transformation and diversity, leadership, employees' wellness, communication, performance management, remuneration and awards, teamwork, work environment and Colegio's image in determining the faculty's job satisfaction. Specifically, the objectives of the study were:

1. To study the relationship of various dimensions of organizational climate and job satisfaction of faculty

2. To study the level perceptions of faculty of Colegio de San Juan de Letran about parameters of organizational climate.

Management situations were one of the issues that members of organizations were most concerned about ( (Chambers, 1978). Whether these issues are trust, training and development, transformation and diversity, leadership, employees' wellness, communication, performance management, remuneration and awards, teamwork, work environment and Colegio's image, they are all closely connected with the fundamental interests of employees. Thus, management style and its operation mode are crucial to the way employees perceive organizational climate, and thus are significant factors affecting organizational climate. Moreover, the faculty's opinions about organizational management style affect their personal performance (Jackson, 1995). Because management is of such great significance for organizations specially academic institutions and their front runners, 
organizational climate in relationship with their jobs satisfaction were investigated in this paper.

\section{THEORIES AND HYPOTHESES}

In this study the possibility of correlation between various dimensions of organizational climate and job satisfaction is proposed with reference to Watkin (2003) who stated that perception of individuals and define climate as a measure of what employees perceive from the environment regarding how work should be done. Taneja (1987) also addresses the climate as the way by which members of the organization comprehend what is important for an effective organization.

An organization cannot create knowledge without individuals. The organization should support creative individuals and provide contexts for them to create knowledge.

Researches have shown that when a man is satisfied with his work, he alone is not benefited but the employee too gets benefit. Besides, satisfaction brings many other tangible and intangible results. The studies in this area have revealed that a person satisfied with his job is likely to profit by having morale in his general living. The community profits on the score of individual and the well-being of the society in general. The person satisfied with job is an asset to the organization and the dissatisfied person is a liability. Thompson, (1995) referred job satisfaction as "a set of attitudes that employees have about their jobs and describe it as the psychological disposition of people towards their jobs, how they feel about the work." (Mundray, 1999) defines satisfaction as the difference between the amount of rewards workers receive and the amount they believe they should receive. When people speak of employee attitudes, more often than not they mean job satisfaction. Tosi et al (1998) define job satisfaction "as a function of the extent to which the task provides a person desired level of both intrinsic and extrinsic outcomes." Education is the largest enterprise. It employs about 60 percent of its product at various types of jobs.

\section{Delimitation of the Study}

1. The study is limited to full time faculty only of Colegio de San Juan de Letran -Bataan.

2. The organizational climate dimensions are limited to trust, training and development, transformation and diversity, leadership, employees' wellness, communication, performance management, remuneration and awards, teamwork, work environment and Colegio's image.

\section{Statistical Techniques}

The following statistical techniques are employed:

1. Descriptive statistics such as - mean median, mode, standard deviation, are used to ascertain the nature of distribution of scores on the various dimensions of organizational climate and job satisfaction.

2. Product moment method of correlation is used for finding the relation between various dimensions of organizational climate and job satisfaction.

\section{Sample Units \& Sampling Techniques}

Since the study is delimited only to all full time faculty of the Colegio de San Juan de Letran-Bataan, there was no longer a need to come up with a sample of the said population. Thus, a universal sampling techniques was adopted. All forty two (42) full time faculty are respondents of the study.

\section{Description of Tool}

The researcher utilized an appropriate standardized instruments which are already developed and widely used (Stone, 1978).

It has 54 questions in four point Likert scale as follows:
1) Strongly Disagree
2) Disagree
3) Agree
4) Strongly Agree

Such standardized instruments provided several advantages. It has been carefully developed over a period of years to accurately measure specific attitudes and perceptions, so reliability and validity have already been proved.

The twelve dimensions of OCQD and serial numbers of items covered are given below in table 1

Table 1

OCQD Dimensions

\begin{tabular}{|c|l|c|}
\hline $\begin{array}{c}\text { Dimension } \\
\text { Number }\end{array}$ & \multicolumn{1}{|c|}{ Dimension } & $\begin{array}{c}\text { \# of items } \\
\text { Covering the } \\
\text { dimensions }\end{array}$ \\
\hline 1 & Trust & 5 \\
\hline 2 & $\begin{array}{l}\text { Training and } \\
\text { Development }\end{array}$ & 5 \\
\hline 3 & $\begin{array}{l}\text { Transformation and } \\
\text { Diversity }\end{array}$ & 4 \\
\hline 4 & Job Satisfaction & 4 \\
\hline 5 & Leadership & 5 \\
\hline 6 & Employees' Wellness & 5 \\
\hline 7 & Communication & 5 \\
\hline 8 & $\begin{array}{l}\text { Performance } \\
\text { management }\end{array}$ & 2 \\
\hline 9 & $\begin{array}{l}\text { Remuneration and } \\
\text { Rewards }\end{array}$ & 5 \\
\hline 10 & Teamwork & 2 \\
\hline 11 & Work environment & 4 \\
\hline 12 & Colegio's Image & \\
\hline
\end{tabular}




\section{Research Model}

The research model utilized in the study incorporated relevant constructs developed in prior studies was

proposed in this study. The comprehensive model is shown in Fig. 1

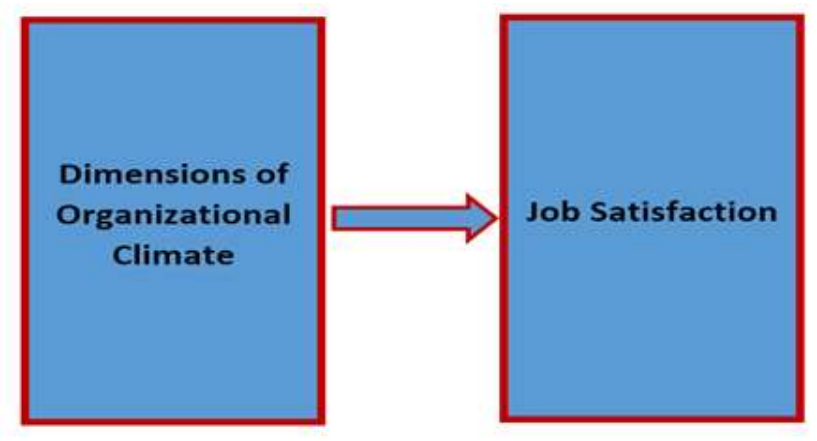

Figure 1.

Research Model

The model is composed of dimensions of organizational climate. These

\section{Results and Discussion}

Table 2

Summary of Respondents' Profile

\begin{tabular}{|c|c|c|}
\hline Department & Frequency & Percent \\
\hline College & 20 & 47.62 \\
\hline High School & 22 & 52.38 \\
\hline Sex & Frequency & Percent \\
\hline Male & 16 & 38.1 \\
\hline Female & 26 & 61.9 \\
\hline Age & Frequency & Percent \\
\hline 20 & 2 & 4.8 \\
\hline 21 & 3 & 7.1 \\
\hline 22 & 3 & 7.1 \\
\hline 23 & 3 & 7.1 \\
\hline 24 & 12 & 28.6 \\
\hline 25 & 3 & 7.1 \\
\hline 26 & 3 & 7.1 \\
\hline 27 & 1 & 2.4 \\
\hline 31 & 1 & 2.4 \\
\hline 33 & 1 & 2.4 \\
\hline 34 & 3 & 7.1 \\
\hline 35 & 1 & 2.4 \\
\hline 38 & 3 & 7.1 \\
\hline 46 & 3 & 7.1 \\
\hline
\end{tabular}

Of the 42 questionnaires distributed, 42 were received, completed and usable. Out of 42 respondents, 20 respondents $(47.62 \%)$ were from college department while $22(52.38 \%)$ were from the basic education department.

Female respondents dominated the population $(61.9 \%)$, and $38.1 \%$ were male dimensions were expected to influence faculty's' job satisfaction.

\begin{tabular}{|c|c|c|}
\hline Educational Attainment & Frequency & Percent \\
\hline College & 40 & 95.2 \\
\hline Graduate Studies & 2 & 4.8 \\
\hline Civil Status & Frequency & Percent \\
\hline Single & 28 & 66.7 \\
\hline Married & 14 & 33.3 \\
\hline \# of years in Letran & Frequency & Percent \\
\hline 1 & 16 & 38.1 \\
\hline 2 & 6 & 14.3 \\
\hline 3 & 10 & 23.8 \\
\hline 4 & 6 & 14.3 \\
\hline 5 & 4 & 9.5 \\
\hline
\end{tabular}

respondents. Most of the respondents were aged 24 years old $(28.6 \%)$ while ages $27,31,33$ and 35 years comprised the lowest number of percentage who got a total frequency of $1(2.4 \%)$

In terms of highest educational attainment, most of the respondents are college degree $(95.2 \%)$ wherein most of them are currently pursuing their masters while $2(4.8 \%)$ respondents are master's degree holder wherein 1 of them is currently pursuing doctorate degree.

Most of the study's respondents are single $(66.7 \%)$ while the remaining $(33.3 \%)$ are married. In terms of length of stay in Letran, most of the respondents are still in their initial year $(38.1 \%)$, while there are 10 respondents $(23.8 \%)$ who have stayed in the Colegio for 3 years. 
Table 3

Summary Mean and Standard Deviation Distribution of Responses on Dimensions of Organizational Climate

\begin{tabular}{|l|c|c|c|}
\hline \multicolumn{1}{|c|}{ Dimensions of Organizational Climate } & Mean & Std. Deviation & Descriptive Remarks \\
\hline Trust & 3.13 & 0.16 & Agree \\
\hline Training and Development & 2.77 & 0.32 & Agree \\
\hline Transformation and Diversity & 2.90 & 0.28 & Agree \\
\hline Job Satisfaction & 2.93 & 0.39 & Agree \\
\hline Leadership & 2.97 & 0.38 & Agree \\
\hline Employees' Wellness & 2.85 & 0.39 & Agree \\
\hline Communication & 2.78 & 0.48 & Agree \\
\hline Performance management & 2.57 & 0.47 & Agree \\
\hline Remuneration and Rewards & 2.85 & 0.50 & Agree \\
\hline Teamwork & 2.59 & 0.51 & Agree \\
\hline Work environment & 2.92 & 0.71 & Agree \\
\hline Colegio's Image & 2.99 & 0.45 & \\
\hline
\end{tabular}

$\begin{array}{rll}\text { Range: } 1.00-1.75 & = & \text { Strongly Disagree } \\ 1.76-2.50 & = & \text { Disagree } \\ 2.51-3.25 & = & \text { Agree } \\ 3.26-4.00 & = & \text { Strongly Agree }\end{array}$

The above table presents the following results: Trust got a mean score of 3.1286 and standard deviation of 0.16 , training and development got 2.77 mean score and 0.32 standard deviation, while transformation and diversity and job satisfaction has a mean value of 2.90 and 2.93 and standard deviation score of 0.28 and 0.39 respectively.

On the other hand, leadership has a mean score and standard deviation score of 2.97 and 0.38 correspondingly. In terms of employees' wellness, it has mean value of 2.85 and standard deviation value of 0.39 , whereas communication dimension of the organizational climate has 2.78 mean value and 0.48 standard deviation score.
Moreover, regarding the performance management of faculty, it got a mean score of 2.57 and standard deviation vale of 0.47 , where, remuneration and rewards acquired 2.85 mean score and 0.50 standard deviation value. Regarding Colegio's work environment, it has a mean score of 2.92 and standard deviation of 0.71 and for the Colegio's image, it acquired a 2.99 mean score, the highest in value, and 0.45 standard deviation. All the acquired mean value has a descriptive remarks of "Agree" white connotes positive experience of the respondent as part of the Colegio's organization. 
Table 4

Coefficient of Correlation between Various Dimensions of Organizational Climate with Job Satisfaction

\begin{tabular}{|l|c|c|c|}
\hline \multicolumn{1}{|c|}{ Organizational Dimension } & $\begin{array}{c}\text { Coefficient of } \\
\text { Correlation }\end{array}$ & $\begin{array}{c}\text { Sig. at 0.05 level } \\
\text { (Phi and Cramers) }\end{array}$ & $\begin{array}{c}\text { Decision } \\
\text { (Null Hypothesis) }\end{array}$ \\
\hline Trust & -0.210 & 0.070 & Accept \\
\hline Training and Development & 0.203 & 0.653 & Accept \\
\hline Transformation and Diversity & 0.120 & 0.070 & Reject \\
\hline Leadership & 0.171 & 0.048 & Reject \\
\hline Employee's Wellness & 0.417 & 0.001 & Reject \\
\hline Communication & 0.342 & 0.000 & Accept \\
\hline Performance Management & 0.244 & 0.142 & Reject \\
\hline Remuneration and Rewards & 0.341 & 0.060 & Reject \\
\hline Teamwork & 0.221 & 0.031 & Reject \\
\hline Work Environment & 0.203 & 0.040 & 0.012 \\
\hline Colegio's Image & 0.006 & 0 & \\
\hline
\end{tabular}

Pearson product moment method of correlation was used to find the relationship of various dimensions of organizational climate with job satisfaction. The values for various coefficients of correlation are given in Table.

The value of correlation between trust and job satisfaction was found to be 0.091 , which is greater than the level of significance. Hence, the relationship there exists significant relationship between trust and job satisfaction stands accepted.

The value of correlation between training and development and job satisfaction was found to be 0.099 , which is less than 0.05 level of significance. Hence, the relationship there exists no significant relationship between training and development and job satisfaction stands accepted.

The value of correlation between transformation and diversity and job satisfaction was found to be 0.225 , which is greater than 0.05 level of significance. Hence, the relationship there exists significant relationship between transformation and diversity and job satisfaction stands accepted.

The value of correlation between leadership and job satisfaction was found to be 0.139 , which is greater than 0.05 level of significance. Hence, the relationship there exists significant relationship between transformation and diversity and job satisfaction stands accepted.

The value of correlation between employee's wellness and job satisfaction was found to be 0.003 , which is less than the 0.05 level of significance. Hence, the relationship there exists no significant relationship between transformation and diversity and job satisfaction stands accepted.

The value of correlation between communication and job satisfaction was found to be
0.013 , which is less than 0.05 level of significance. Hence, the relationship there exists no significant relationship between communication and job satisfaction stands accepted.

The value of correlation between performance management and job satisfaction was found to be 0.060 , which is greater than 0.05 level of significance. Hence, the relationship there exists no significant relationship between performance management and job satisfaction stands accepted.

The value of correlation between remuneration and rewards and job satisfaction was found to be 0.014 , which is less than 0.05 level of significance. Hence, the relationship there exists no significant relationship between remuneration and rewards and job satisfaction stands accepted.

The value of correlation between teamwork and job satisfaction was found to be 0.079 , which is greater than 0.05 level of significance. Hence, the relationship there exists significant relationship between teamwork and job satisfaction stands accepted.

The value of correlation between work environment and job satisfaction was found to be 0.099 , which is greater than 0.05 level of significance. Hence, the relationship there exists no significant relationship between teamwork and job satisfaction stands accepted.

The value of correlation between Colegio's image and job satisfaction was found to be 0.484 , which is greater than the table value of 0.195 at 0.05 level of significance. Hence, the relationship there exists significant relationship between Colegio's image and job satisfaction stands accepted. 


\section{FINDINGS}

1. There is significant relationship between dimensions of transformation and diversity and Colegio's image of organizational climate and job satisfaction.

2. There is no significant relationship between dimensions of trust, training and development, leadership, employee's wellness, communication, performance management, remuneration and rewards, teamwork and work environment of organizational climate and job satisfaction.

\section{Educational Implications}

The principal is the key person in any school. He is not only responsible for his own behavior in as far as the aspects of organizational climate are concerned but he is more or less responsible for behavior of the teachers. In order to build up a sound organizational climate, administrators must understand teachers in the school. The importance must be given to what

\section{WORKS CITED}

1. Chambers, H. (1978). Psychology of Human Behavior. New Jersey: McGraw Hill Book Company, Inc.

2. Croft, S. (1963). Organizational Climate Descriptive Questionnaire. New York: New York Publishing Inc.

3. Jackson, C. (1995). Human Organization. School Management: How To, 32.

4. Liano, M. (2001). School Climate: Where to? Educational Psychological Approach, 11.

5. Mundray, H. M. (1999). Organizational Behavior and Work Assessment. Mississippi: Academia Inc. motivates job performance in general and building an overall climate conducive to motivation of the teachers.

\section{RECOMMENDATIONS}

On the basis of the above results, following recommendations may be given

1. The present study deals with college and high school faculty of Colegio de San Juan de Letran. It may be replicated at any college or university

2. An investigation may be designed to compare the job satisfaction level of teachers working in public and private schools.

3. A comparative study of organizational climate of schools in rural and urban areas can also be studied.

4. Organizational climate and its relationship with academic achievement of students may also be an area of paramount importance for further research.

6. Stone, H. A. (1978). Validated Instruments. Arizona.

7. Taneja, R. P. (1989). Dictionary of Education. New Delhi: Annol Publishers.

8. Thompson, J. (1995). Organizational Climate and Teacher Job's Satisfaction. AdMus Journal, 18-21.

9. Watkin, W. A. (2003). Organizational Climate in Schools and Job Satisfaction of Teachers. International Education Kansas Education. 